УДК 342.7

DOI https: / / doi.org/10.32837/yuv.v0i4.983

\author{
Л. Адашис, \\ кандидат юридичних наук, доцент, \\ доцент кафедри міжнародного права \\ навчально-наукового інституту права та міжнародно-правових відносин \\ Університету митної справи та фінансів
}

\title{
А. Левдик,
}

провідний фахівець-юрисконсульт юридичного відділу

Університету митної справи та фінансів

\section{ОСОБЛИВОСТІ ЗАСТОСУВАННЯ СУДАМИ УКРАЇНИ ПРАКТИКИ ЄСПЛ В КОНТЕКСТІ ЗАХИСТУ ПРАВА НА СПРАВЕДЛИВИЙ СУДОВИЙ РОЗГЛЯД ТА ПРАВА НА ЕФЕКТИВНИЙ ЗАСІБ ЮРИДИЧНОГО ЗАХИСТУ}

Постановка проблеми. Підвищення ефективності та дієвості механізмів із захисту прав людини в нашій державі (в першу чергу судових механізмів) повинно бути пріоритетним напрямом курсу на гуманізацію державної політики у всіх сферах. Сьогодні ми можемо спостерігати позитивну тенденцію відходу судів від суто нормативістського підходу до вирішення справ на користь природно-правового, який дає змогу зорієнтувати правосуддя в антропоцентристському напрямку.: Значну роль у розвитку зазначеної тенденції відіграє як закріплення на законодавчому рівні відповідних вимог (Закон України "Про виконання рішень та застосування практики Європейського суду з прав людини") так і все активніше застосування національними судами під час винесення вироків практики Європейського суду з прав людини (далі - ЄСПЛ) в якості джерела права.

В межах цього дослідження ми б хотіли звернутись до національного досвіду застосування судами України практики ЄСПЛ в контексті захисту права на справедливий судовий розгляд та права на ефективний засіб юридичного захист, як базових, на нашу думку, принципів здійснення правосуддя.
Аналіз останніх досліджень i публікацій. Питання застосування практики ЄСПЛ національними судами України увійшли до сфери наукових інтересів таких дослідників, як М. В. Буроменський, В. Г. Буткевич, В. Н. Денисов, О. М. Ерделевський, В. І Євінтов, В. К. Забігайло, Л. Г. Заблоцька, Є. Б. Кубком, B. Є. Мармазов, А. С. Мацко, В. В. Міцик, В. І. Муравйов, І. С. Піляєв, П. М. Рабінович, С. В. Шевчук, С. Є. Федик. Однак лише Ю. І. Матат, Т. М. Мирошниченко, Е. Л. Трегубов досліджували саме право на справедливий судовий розгляд та ефективний засіб юридичного захисту в контексті практики ЄСПЛ та національного правозастосування.

Виділення не вирішених раніше частин загальної проблеми. У зв'язку з динамікою зміни нормативної бази, що визначає вимоги до здійснення правосуддя, видається доцільним дослідження національного підходу до застосування відповідної практики ЄСПЛ втому числі в контексті реформування судової системи 3 метою надання відповіді на запитання "Чи змінився підхід національних судів до застосування практики ЄСПЛ під час захисту права на справедливий судо- 


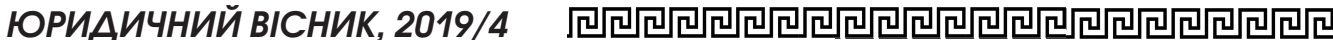

вий розгляд та ефективний засіб юридичного захисту?”.

Мета статті полягає у комплексному аналізі особливостей застосування судами України практики ЄСПЛ в контексті захисту права на справедливий судовий розгляд та права на ефективний засіб юридичного захисту.

Виклад основного матеріалу. Право на справедливий суд гарантується особі в силу вимог статті $6 \mathrm{KoH}-$ венції про захист прав людини і основоположних свобод (далі - Конвенція), згідно якої право на справедливий і публічний розгляд справи упродовж розумного строку незалежним і безстороннім судом, встановленим законом, при визначенні цивільних прав і обов'язків особи чи при розгляді будьякого кримінального обвинувачення, що пред'являється особі.

Право на ефективний засіб юридичного захисту гарантується особі 6 статтею Конвенції, у відповідності до якої, кожен, чиї права та свободи, визнані в цій Конвенції, було порушено, має право на ефективний засіб юридичного захисту в національному органі, навіть якщо таке порушення було вчинене особами, які здійснювали свої офіційні повноваження [1].

Отже, під час здійснення правосуддя додержання цих прав громадян $є$ пріоритетним, оскільки саме закріплення цих прав гарантує те, що правовий спір буде вирішено національним судом із додержанням принципів добросовісності, рівності сторін та правової визначеності.

Право на справедливий суд можна назвати багатоелементним, віднісши до нього 1) право на розгляд справи; 2) справедливість судового розгляду; 3) публічність розгляду справи та проголошення рішення; 4) розумний строк розгляду справи; 5) розгляд справи судом, встановленим законом; 6) незалежність і безсторонність суду.

Досліджуючи витоки сучасного розуміння права на справедливий суд, О. Ткачук зазначає, що право на справедливий судовий розгляд $€$ проце- суальним правом кожного, чиї права порушені, не визнані чи оспорюються. Суть цього права полягає в тому, що, по-перше, воно є правом для захисту інших прав, а по-друге, це право має власну самодостатню цінність як складовий елемент принципу верховенства права [2, с. 193].

Аналіз практики національних судів дає змогу стверджувати, що зазвичай найбільш часто порушується право особи на розумний строк розгляду справи у поєднанні 3 відсутністю ефективних засобів юридичного захисту. Як вдало зазначає з цього приводу С. Кулицька, проблема розгляду справ у розумні строки в Україні має комплексний характер, проявляється в усіх видах проваджень та потребує якнайшвидшого вирішення, оскільки становить один із ключових факторів, що призводить до констатації Європейським судом із прав людини порушень Україною положень Конвенції про захист прав людини і основоположних свобод [3, с. 121].

В зв'язку з вищеозначеним показовою, на нашу думку є постанова Великої палати Верховного Суду (далі - ВП BC) у справі №1-184/2002 від 05 червня 2019 року. Суть справи полягає в тому, що вироком Слов'янського міськрайонного суду Донецької області від 10 грудня 2004 року особу було визнано винним у вчиненні злочину, передбаченого ч. 2 ст. 368 Кримінального кодексу України. Ухвалою Апеляційного суду Донецької області від 10 березня 2009 року вказаний вирок змінено. Дії особи було перекваліфіковано з ч. 2 ст. 368 КК України на ч. 5 ст. 27 - ч. 2 ст. 368 КК України. Ухвалою Верховного Суду України від 13 жовтня 2009 року відмовлено у задоволенні касаційної скарги обвинуваченого.

Обвинувачений та три інші особи звернулись до ЄСПЛ у зв'язку із порушенням $\ddot{i x}$ прав на справедливий суд та відсутність у національному законодавстві ефективного засобу юридичного захисту. У рішенні 
Європейського суду з прав людини (далі - ЄСПЛ) від 6 грудня 2018 року у справі "Вега та інші проти України" (заява № 51414/07 від 13 листопада 2007 року) було констатовано порушення пункту 1 статті 6 та статті $13 \mathrm{KoH}-$ венції про захист прав людини і основоположних свобод (далі - Конвенція). Зокрема, у пункті 1 Додатку до вказаного рішення ЄСПЛ встановлено надмірну тривалість кримінальних проваджень та відсутність у національному законодавстві ефективного засобу юридичного захисту (початок провадження 26 квітня 2002 року - закінчення провадження 13 жовтня 2009 року) і присуджено заявнику 900 євро як відшкодування моральної та матеріальної шкоди, судових та інших витрат.

У лютому 2019 року обвинувачений звернувся до Верховного Суду із заявою про перегляд вироку Слов'янського міськрайонного суду Донецької області від 10 грудня 2004 року та ухвали Апеляційного суду Донецької області від 10 березня 2009 року 3 підстав встановлення міжнародною судовою установою, юрисдикція якої визнана Україною, порушення Украіною міжнародних зобов`язань при вирішенні справи судом. Обвинувачений просив скасувати зазначені судові рішення, а справи направити на новий судовий розгляд до суду першої інстанціï.

Однак, у п. 17, 22 Постанови ВП BC зазначила, що вимоги особи про скасування судових рішень щодо нього та передання справи на новий розгляд у суд першої інстанції фактично мають на меті реалізацію права на такий захід індивідуального характеру, як відновлення настільки, наскільки це можливо, попереднього юридичного стану, який заявник мав до порушення Конвенціï (restitutio in integrum). Негативних наслідків через констатовані ЄСПЛ порушення, зокрема через надмірну тривалість кримінального провадження, особа вже не зазнає. Тому такий додатковий захід індивідуального характеру, як повторний розгляд його справи зі скасуванням вироку Слов'янського міськрайонного суду Донецької області від 10 грудня 2004 року, ухвали Апеляційного суду Донецької області від 10 березня 2009 року та направленням справи на новий розгляд у суд першої інстанції не призведе до поновлення його права на розгляд справи упродовж розумного строку [4].

Таким чином, заявнику було відмовлено у задоволенні заяви та залишено без змін відповідні вирок та ухвалу.

Вказана справа $є$ показовою з огляду на те, що є наочним прикладом того, наскільки національними судами порушується право на справедливий суд (більше дванадцяти років особа змушена звертатись до судових інстанцій 3 метою реалізації свого права) та фактично репрезентуе загальний формальний підхід національних судів до розгляду справ в контексті відсутності ефективного засобу захисту такого порушеного права.

На підтвердження означеного, аналізуючи релевантність застосування практики ЄСПЛ, Р. Бабанли та П. Пушкар вдало зазначають, що застосування практики ЄСПЛ вимагає переосмислення. У тому числі переосмислення вимагають аспекти як (не)релевантного, так і (не)доречного застосування практики ЄСПЛ. Іншими словами, слід розглянути можливість формування "культури" імплементації практики ЄСПЛ з урахуванням виявлених проблем, а також з огляду на існуючі прогалини: застосування практики там, де це не вимагається, та незастосування практики там, де це вимагається. Застосування практики Суду та посилання на рішення Європейського суду не повинно бути автоматичним - цей процес повинен мати логічне підгрунтя. Сама Конвенція не вимагає прямого застосування (посилання на) ii положень(ня). Основна вимога Конвенції, відповідно до ст. 1 - забезпечувати реалізацію та виконання вимог щодо прав людини, в каталозі прав закріплених Конвенцією та протоколами до неї. Чи забезпечить реаліза- 


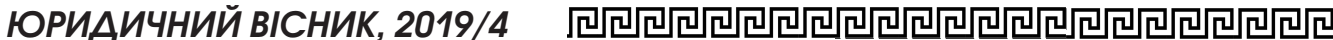

цію конвенційних прав національний Суд з посиланням на вимоги Конвенції чи на практику Суду чи без такого посилання - питання відкрите. Раціональність посилань, юридична обгрунтованість та sensus communis повинні стати ключовими критеріями релевантності та доречності посилань на практику та рішення ЄСПЛ [5].

Порушення у відповідних процесуальних кодексах строків, у які повинні здійснювати конкретні процесуальні дії або в рамках яких мають місце конкретні процесуальні стадіі, на нашу думку, є навіть більш значною проблемою ніж, наприклад, корупція у судовій системі, оскільки саме ця проблема демонструє загальний нігілізм судової системи по відношенню до права громадян на справедливий суд. В той же час, на наше глибоке переконання, про ефективність роботи судів в контексті правозахисного вектору їх діяльності повинен свідчити саме рівень довіри громадян. Однак, на сьогодні, не зважаючи на проведену судову реформу, такий рівень довіри до судових органів збоку громадян є невисоким.

Згідно даних Центру Соціологічних досліджень Разумкова, для більшості громадян функціонування суду в Україні $€$ незрозумілим, вони вважають, що суди вирішують справи повільно, а витрати на доступ до правосуддя $€$ високими. Оцінювання відбувалося за шкалою від “0” до "6" балів, де оцінка "0" означала “незрозуміло”, “повільно”, “витрати високі”, відповідно, а оцінка “6” означала “зрозуміло”, “швидко”, “витрати низькі”, відповідно. Оцінюючи зрозумілість функціонування суду - середня оцінка склала 2,1 балів, відповідно, швидкість вирішення справ отримала 1,7, а такий аспект як витрати на доступ до правосуддя - 1,6 балів. Краще (крім оцінки щодо витрат на судовий процес) оцінили ситуацію респонденти, яким доводилося протягом останніх двох років брати участь у розгляді судових справ. Серед цієї категорії респондентів середня оцінка зрозумілості функціонування суду склала 2,7 балів (що, фактично, є середньою оцінкою), середня оцінка швидкості вирішення справ склала 2,1 балів, а середня оцінка стосовно витрат на доступ до правосуддя - 1,7 балів. Порівняно з 2017 роком оцінки практично не змінилися [6].

Підтвердженням вищеозначеного може також слугувати і результати Моніторингу судових процесів в Украіні, проведеного у 2017 році Центром політико-правових реформ за підтримки Координатора проектів ОБСЕ в України. Згідно загального висновку за результатами моніторингу, було зафіксовано значні порушення принципу розумності строків розгляду (кожне друге призначене судове засідання взагалі не відбувалось) [7, с. 88].

Ще однією проблемою в цьому контексті є недостатньо високий рівень поінформованості учасників процесу щодо їх прав, а також про процедуру судового розгляду та звернення до ЄСПЛ у разі виявлення порушень. О. Гаврилюк вказує на істотні проблеми у застосуванні практики ЄСПЛ під час розгляду та вирішення справ у національних судах, що пов'язані передусім із недоступністю рішень ЄСПЛ, ухвалених проти інших держав, через відсутність їх перекладів, а також браком загальної культури та навичок застосування практики ЄСПЛ як серед учасників процесу, так і серед суддів, що потребує невідкладних заходів 3 боку держави, пов'язаних зі створенням відповідних баз даних із доступними перекладами практики ЄСПЛ українською [8, с. 237].

Висновки та пропозиціï. На нашу думку, подолання зазначених проблем можливо виключно за комплексного підходу, який включав би в себе інституційну (оптимальна організація судової системи), нормативну (наявність якісно сфрормульованих на рівні юридичної техніки процесуальних норм) та правоосвітню (юридична обізнаність громадян щодо власних прав та механізмів їх захисту) складові. Тож якщо 
ЄСПЛ визнає факт порушення прав заявника з боку держави-відповідача, така держава зобов'язана не тільки вжити заходів індивідуального характеру (наприклад, виплатити справедливу сатисфакцію чи здійснити перегляд справи у судовому порядку), але також вжити певних заходів загального характеру 3 метою усунення зазначеної в рішенні ЄСПЛ системної проблеми та іï першопричини - недоліків системного характеру, які лежать в основі виявленого ЄСПЛ порушення. Як наслідок, будуть усунені підстави для повторного звернення в ЄСПЛ з тих причин, які вже були предметом його розгляду.

Зауважимо, що часто саме формальний підхід національних судів під час розгляду справ, у яких особа посилається на практику ЄСПЛ та/або Конвенцію, а також фактичне тлумачення відповідними судовими органами окремих рішень призводить до повторних звернень громадян до ЄСПЛ часто 3 позитивним результатом розгляду таких скарг. 3 метою мінімізації подібних ситуацій пропонується подальша розробка на доктринальному рівні рекомендацій та узагальнень із правильного розуміння та застосування відповідної практики ЄСПЛ національними судами.

Дослідження присвячено аналізу правової сутності права на справедливий судовий розгляд та права на ефективний засіб юридичного захисту як основних прав людини, пов'язаних зі здійсненням правосуддя. $В$ статті досліджуеться сутність $i$ зміст понять "право на справедливий судовий розгляд" та "право на ефективний засіб юридичного захисту". Авторами також вивчається нормативне закріплення изих прав у міжнародному та національному законодавстві. Основна частина дослідження присвячена аналізу національної судової практики, пов'язаної із застосуванням рішень Європейського суду з прав людини щодо захисту вищеозначених прав.
За результатами дослідження автори констатують, щз національними судами у правозастосовній діяльності досить часто порушується право на справедливий суд. Автори роблять висновок, що під час здійснення судами правосуддя на національному рівні домінуе формальний підхід судів до розгляду справ в контексті відсутності ефективного засобу захисту порушеного права сторони судового розгляду. також резюмується значна кількість у національному правозастосуванні прямих та опосередкованих законодавчих обмежень та неформальних практик, що перешкоджають реалізації права громадян на справедливий судовий розгляд.

Пропонується комплексний підхід до подолання зазначених проблем, який включав би в себе інституиійну (оптимальна організація судової системи), нормативну (наявність якісно сформульованих на рівні юридичної техніки процесуальних норм) та правоосвітню (юридична обізнаність громадян щздо власних прав та механізмів їх захисту) складові.

Ключові слова: Європейський суд із захисту прав людини, права та свободи, право на справедливий суд, ефективні засоби юридичного захисту, право на ефективні засоби судового захисту.

Adashis L., Levdik A. THE COURT
APPLICATION'S PECULIARITIES
OF THE ECHR PRACTICE IN THE
CONTEXT OF THE RIGHT TO
JUSTIFY JUDICIAL'S AND THE
RIGHT TO EFFCTIVE MEANS
OF THE LEGAL ENTITIES
PROTECTION

The study examines the legal nature of the right to a fair trial and the right to an effective remedy as a fundamental human right related to the administration of justice. The article explores the essence and content of the concepts of "right to a fair trial" and "right to an effective 


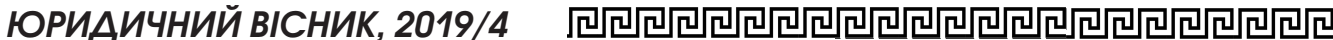

remedy". The authors also study the normative enforcement of these rights in international and national law. The main part of the study is devoted to the analysis of national jurisprudence related to the application of European Court of Human Rights judgments on the protection of the above rights.

According to the results of the study, the authors state that the right to a fair trial is often violated by national courts in law enforcement activities. The authors conclude that the judicial process at national level is dominated by the formal approach of the courts to hear cases in the context of the absence of an effective remedy for the violated right of a party to trial. It's also summarized that the considerable amount of direct and indirect legislative restrictions and informal practices that impede the exercise of the right of citizens to a fair trial in national enforcement.

It is also summarized that it is often the formal approach of national courts when considering cases in which a person refers to ECtHR practice and / or the Convention, as well as the factual interpretation of individual decisions by the relevant judicial authorities that results in repeated appeals to the ECtHR, often with a positive outcome of such complaints. In order to minimize such situations, it is proposed to further develop, at the doctrinal level, recommendations and generalizations on the proper understanding and application of relevant ECtHR practices by national courts.The authors propose a comprehensive approach to overcoming these problems, which would include institutional (optimal organization of the judicial system), regulatory (availability of qualitatively formulated procedural rules at the level of legal technology) and legal educational (legal awareness of citizens about their rights and mechanisms for their protection) parts.

Key words: European Court of Human Rights, Rights and Freedoms, right to a fair trial, effective remedies, right to an effective remedy.

\section{Література:}

1. Конвениія про захист прав людини i основоположних свобод. URL: https:// zakon.rada.gov.ua/laws / show /995_004

2. Ткачук О. Витоки сучасного розуміння права на справедливий суд. Visegrad Journal on Human Rights. 2016. №1. C.188-193.

3. Куліцька С. Ефективні засоби захисту права на справедливий суд (у частині дотримання розумних строків) в Україн: місія здійсненна? Visegrad Journal on Human Rights. 2016. №1. C.121-126

4. Постанова Великої палати Верховного Суду у справі №1-184/2002 ві 05 червня 2019 року. URL: http:// reyestr. court.gov.ua / Review / 82308655

5. До питання про (не)релевантне застосування практики Європейського суду з прав людини: практичні nopadu URL: http://pgp-journal.kiev.ua/ archive / 2018/4/40.pdf

6. Ставлення громадян України до судової системи (соціологічне дослідження). URL: http: / / razumkov.org.ua / napriamky/ sotsiologichni-doslidzhennia/stavlenniagromadian-ukrainy-do-sudovoi-systemy

7. Звіт про результати першої програми моніторингу судових процесів в Україні. Дотримання права на справедливий суд 2017 у судових процесах України. URL: http://pravo.org.ua/img / books / files / 15375263701529318084povny_zvit_sud. pdf

8. Гаврилюк О. Проблемні питання застосування практики європейського суду з прав людини національними судами. Підприємництво, господарство $і$ право. 2018. №4. C. 231-238

9. Фулей T. I. Застосування практики Європейського суду з прав людини при здійсненні правосуддя: Науково-методичний посібник для суддів. - 2-ге вид. випр., допов. K., 2015. 208 c. 